\title{
Sludge Reduction and General Performance in a Combined US+OSA System
}

\author{
P. M. Romero-Pareja, C. A. Aragon-Cruz, J. M. Quiroga-Alonso, and D. Coello-Oviedo
}

\begin{abstract}
The reduction of sewage sludge generated in wastewater treatment plants is one topic of interest due to the high cost related to the management of this waste and the rising amount of volume at which sludge is produced worldwide. Within the techniques to reduce sludge, the Oxic-Settling-Anaerobic (OSA) process is one of the most promising due to its simplicity and to the absence of negative consequences for system. In the OSA process the recycled sludge is submitted to an anaerobic stage prior to flow again into the biological reactor. In this study, OSA process is run in a lab scale pilot plant together with a lysis step by ultrasound treatment, applied daily to a certain fraction of the total sludge of the system previously to the anaerobic holding tank. Results point to an enhancement of sludge reduction rate for the two sonication applied regimes $(45.72 \%$ and $78.56 \%)$. Also the TN removal rate increases from $21.95 \%$ during control stage to $47.28 \%$ during the first of the two ultrasound regimes applied (US1). A too intense sonication treatment during the second synergic stage (US2) is reported to lead to a serious damage of system. Increases of dehydrogenase activity were described during both stages.
\end{abstract}

Index Terms-Activated sludge process, excess sludge reduction, OSA process, ultrasound.

\section{INTRODUCTION}

The number of municipal wastewater treatment plants (WWTP) is increasing remarkably worldwide, leading to a rising amount of produced sludge, a by-product of sewage treatment. In general, the activated sludge process (ASP), shows an average excess sludge production of $0.4-0.6$ $\mathrm{gVSS} / \mathrm{gCODremoved} \mathrm{[1].} \mathrm{The} \mathrm{management} \mathrm{of} \mathrm{this} \mathrm{waste} \mathrm{has}$ a related cost of up to $65 \%$ of the total operating costs of a WWTP [2] The reduction of excess sludge in the water line of wastewater treatment process is preferable to that in the sludge line (e.g.: digestion) as the latter intends to reduce was at origin. One of the most effective techniques for sludge reduction is the Oxic-Settling Anaerobic (OSA) process that is based on the insertion of an anaerobic tank in the recycled sludge line [1]. This technique has shown sludge reduction rates from $20 \%$ to $60 \%$ [2]. Ultrasonication is a technique based on cell lysis-cryptic growth technique [3] The present study shows result of a treatment combining ultrasonication

Manuscript received October 4, 2016; revised February 5, 2017. This work was supported by the Consejeria de Ciencia e Innovacion de la Junta de Andalucía, Spain (under the grant: Proyecto Excelencia No. P09-TEP-4539, financed by ERDF funds

P. M. Romero-Pareja, J. M. Quiroga-Alonso, and D. Coello-Oviedo are with Environmental Technologies Department, University of Cadiz, Spain (e-mail: Pablo.romero@uca.es).

C. A. Aragon-Cruz is with Foundation Center for New Water Technologies, CENTA, Seville, Spain (e-mail: caragon@centa.es). and OSA process at lab-scale highlighting the results in terms of sludge reduction, but also exposing results of fate of TN removal rate and microbial activity in sludge of system.

\section{MATERIALS AND METHODS}

The pilot plant was made with methacrylate with volumes of 12,4 , and $10 \mathrm{~L}$ for aerobic reactor, settling unit and anaerobic tank (OSA), respectively. The dissolved oxygen in aerobic reactor was set at $3 \mathrm{mg} \mathrm{O}_{2} / \mathrm{L}$. Three periods were distinguishable during study of 40, 40, and 30 days of duration, respectively. During the first stage (ASP or conventional stage) the pilot plant was run as a conventional ASP. The hydraulic residence time (HRT) was $9 \mathrm{~h}$. Later, OSA anaerobic tank was introduced in recirculation line for the following periods. Next phases are referenced as US1 and US2, during which, in addition to the OSA process, ultrasonication technique (Sonics Vibracell VCX 750 device) was applied daily to a specific fraction of recycled sludge. Parameters of ultrasonication treatment are collected in Table I. The sludge anaerobic exposure time (SAET) and the HRT were kept at 6 and $9 \mathrm{~h}$, respectively. Layout of pilot plant during US stages is shown in Fig. 1.

Sludge sonication ratio, SP, is the ratio between amount of sludge ultrasonicated daily and total mass of sludge in system The influent was characterized every two weeks and average values and standard deviation obtained were $307.49 \pm 21.01$ $\mathrm{mg} \mathrm{O}_{2} / \mathrm{L}$ and $48.62 \pm 6.13 \mathrm{mg} \mathrm{N} / \mathrm{L}$ in terms of COD and TN

All measurements were carried out according to Standard Methods [4]. Dehydrogenase activity (DHA) was determined using Romero et al. [5]. Total nitrogen (TN) was measured on a Shimadzu TOC-LCPH with TN measurements.

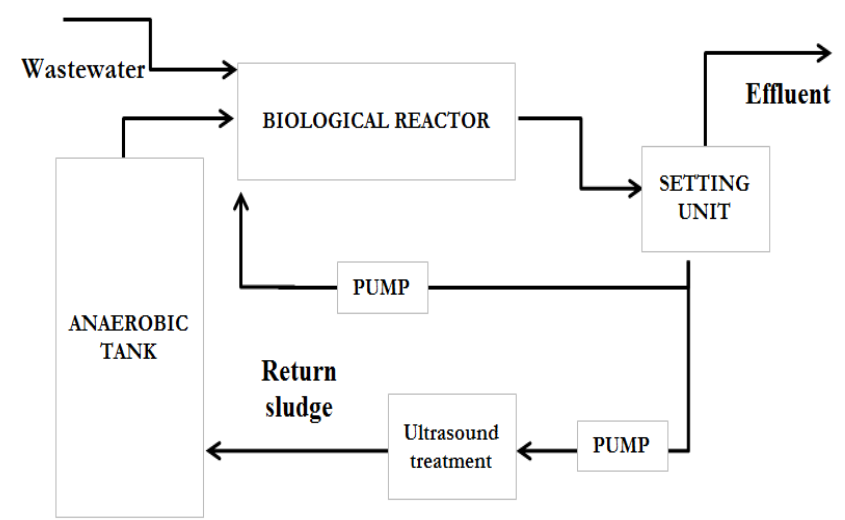

Fig. 1. Layout of US+OSA plant.

The calculation of accumulated sludge in the system throughout the study was carried out as the sum of total sludge in system (aeration and anaerobic tanks), in waste sludge and the solids washed out in effluent. 
TABLE I: CHARACTERISTICS OF US TREATMENT IN US1 AND US2 STAGES

\begin{tabular}{llll}
\hline \hline & & $\mathrm{US} 1$ & $\mathrm{US} 2$ \\
\hline Frequency US & $\mathrm{kHz}$ & 20 & 20 \\
\hline Power density & $\mathrm{W} / \mathrm{ml}$ & 0.375 & 0.375 \\
\hline $\begin{array}{l}\text { Frequency } \\
\text { treatment }\end{array}$ & $\mathrm{d}-1$ & 3 & 4 \\
\hline $\begin{array}{l}\text { Energy applied } \\
\text { (each treatment) }\end{array}$ & $\mathrm{kJ}$ & 90 & 120 \\
\hline $\begin{array}{l}\text { Specific ultrasonic } \\
\text { energy, ES (avg.) }\end{array}$ & $\mathrm{MJ} / \mathrm{kg} \mathrm{TS}$ & 35.9 & 62.0 \\
\hline $\begin{array}{l}\text { Sludge sonication } \\
\text { ratio, SP (avg.) }\end{array}$ & $\%$ & 7.8 & 11.5 \\
Duration of stage & $\mathrm{d}$ & 40 & 30 \\
\hline \hline
\end{tabular}

\section{RESULTS AND DisCUSSION}

\section{A. Excess Sludge Production}

The accumulation of sludge production during the three stages of study is shown in the Fig. 2.

The average daily sludge production were $2.010 \mathrm{~g} / \mathrm{d}, 1.091$ $\mathrm{g} / \mathrm{L}$, and $0.434 \mathrm{~g} / \mathrm{L}$ for conventional phase (ASP), US1, and US2 stages, respectively, meaning a sludge reduction rate of $45.72 \%$ and $78.56 \%$ in the US+OSA phases. The reduction rate at US1 stage is higher than rates obtained for similar OSA processes (without ultrasonication): $11.5-33 \%$ [6], $18.3 \%$ [7], $19.85 \%$ [8], and 32\% [9].

The improvement of reduction of sludge process might be adduced to exposed phenomena: enhancement of endogenous functions of sludge with ultrasonication treatment [10] increment of available lysed substrate and subsequent cryptic growth and increase of biodegradability of COD [11]. At the same time, the sludge reduction rate registered at US2, 78.56\% is direct consequence of decrease of solid concentration in aerobic reactor, undesirable fact leading to a deficient performance of plant.

On the other hand, a higher influence of ultrasonication on sludge reduction would be expectable if solid concentration of sludge submitted to ultrasonication were higher [12]. Sludge concentrations in anaerobic tank were of $5015 \mathrm{mg}$ MLSS/ $1 \pm 134$ and $4861 \mathrm{mg}$ MLSS/ $1 \pm 516$ for US1 and US2 stages, respectively, and in the aerobic reactor, $3874 \mathrm{mg}$ MLSS/ \pm 196 for US1. For the US2 stage, the solid concentration showed a continuous decrease to a minimum concentration of $2.462 \mathrm{mgMLSS} / \mathrm{l}$.

\section{B. COD Removal}

The COD removal rates for the system were $89.64 \pm 5.19$, 93.21 \pm 3.47 , and $84.61 \pm 5.49$ for conventional phase, US1, and US2. So, it can be concluded that the COD removal was good throughout the study. Though the system during stage US2 was damaged cause to a too intense ultrasonication treatment, the average COD removal rate was over $75 \%$, but lower than COD removal rates of previous stages, due to the cell decay. The light improvement of COD removal at US1 stage, leads to the finding that ultrasound did not damage COD removal capacity of biological system when treatment is not too intense as in this phase [1]-[13]. Rodriguez- Perez et al [14] reported low active biomass fraction in sludge from OSA process, but with higher metabolism activity than sludge from conventional ASP, enabling a better COD removal performance. Also, enhancement of biological activity with ultrasonication, leading to a higher COD removal rate was also reported by Wang et al. [15]. The fact that anaerobic tank of OSA process was placed after ultrasonication step is also cause of the good assimilation of the released COD during lysis technique. This consumption of substrate in the holding tank is one of the reported mechanisms for sludge reduction in OSA process as anaerobic metabolic processes are linked to lower growth yield and gaseous products [16] entails.

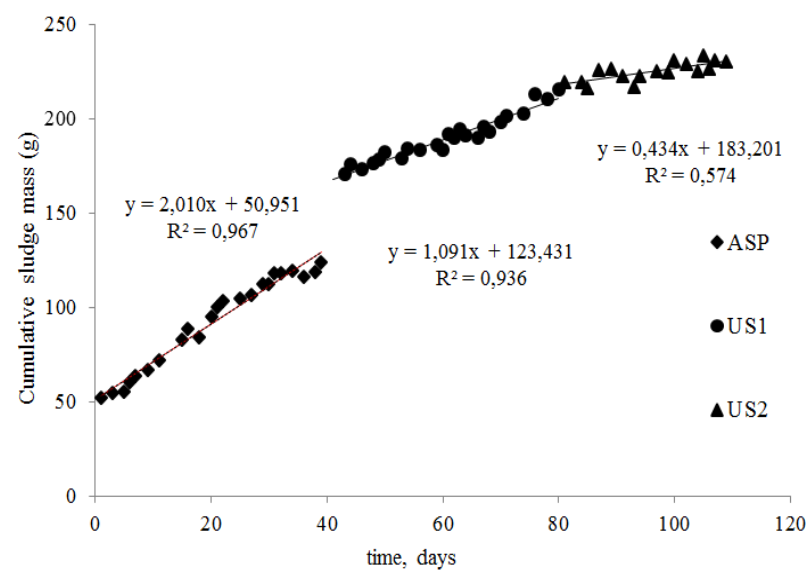

Fig. 2. Cumulative sludge produced during the study.

\section{C. $p H$}

The average values and standard deviation of $\mathrm{pH}$ in the reactor and in effluent from the different stages of study are reported in Table II.

The $\mathrm{pH}$ of sludge from aerobic reactor showed a clearly increase when the recycled sludge was submitted to ultrasonication and to anaerobic exposition. The $\mathrm{pH}$ increase of the aerobic sludge in an OSA system had been previously reported [8]. In that study, it was commented that release of fatty volatile acids (FVA) for higher SAET would lead to a decrease in $\mathrm{pH}$ in anaerobic tank. Moreover, the observed increase of $\mathrm{pH}$ could be also due to the ultrasonication [12]. The values of $\mathrm{pH}$ registered in aerobic reactor at US1 and US2 stages are also adequate for nitrification. The effluent showed for all stages of the study a similar increase in comparison to the $\mathrm{pH}$ of aerobic reactor.

TABLE II: AVERAGE VALUES OF PH

\begin{tabular}{llll}
\hline & ASP & US1 & US2 \\
\hline Effluent & $7.37 \pm 0.14$ & $7.84 \pm 0.13$ & $7.89 \pm 0.09$ \\
Aerobic reactor & $7.14 \pm 0.28$ & $7.43 \pm 0.20$ & $7.45 \pm 0.12$ \\
\hline \hline
\end{tabular}

\section{Dehydrogenase Activity}

The measured values of dehydrogenase (DHA) activity for the three stages of study are depicted in the Fig. 3.

The ASP stage was reported to have an average value of DHA activity of $27.63 \mathrm{mgO}_{2} /(\mathrm{gVSS} \cdot \mathrm{d}) \pm 2.17$. During the first combined stage, US1, DHA activity was enhanced to an average value of $33.16 \mathrm{mg} \mathrm{O} /(\mathrm{gVSS} \cdot \mathrm{d}) \pm 1.49$, which supposes a $20.01 \%$ increase. This fact has been reports previously [5], [17], [18]. Increase of DHA activity may be adduced to the enhancement of endogenous metabolism, as required energy for labors of cell maintenance and reparation 
increases with ultrasonication treatment [17], which is, at the same time, one reason for the increase of the sludge reduction rate observed in the synergic system. When ultrasonication treatment was configured to operate at US2 phase, DHA activity decreased acutely from day 85 . The ultrasonication treatment was too intense during this stage damaging the balance of cell restoration, leading also to the decrease of solids concentration mentioned previously. Specifically, the average value of DHA activity at US2 was $25.44 \mathrm{mg} \mathrm{O}_{2} /$ $(\mathrm{gVSS} \cdot \mathrm{d}) \pm 5.87$, with clear decreasing trend. Marin [18] also reported different trends of biomass activity as a function of the applied ES. When it is below $20 \mathrm{MJ} / \mathrm{kg}$ TS as in the present study, the trend was positive in comparison to the conventional system and when ES was higher, biomass activity showed a decreased.

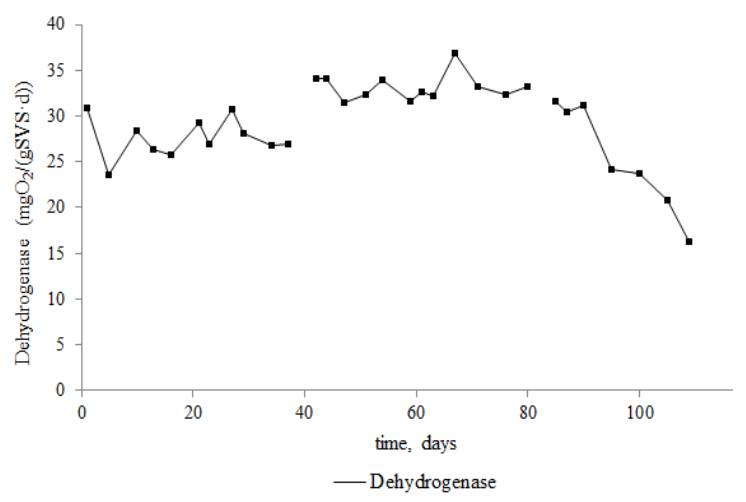

Fig. 3. Dehydrogenase activities during study.

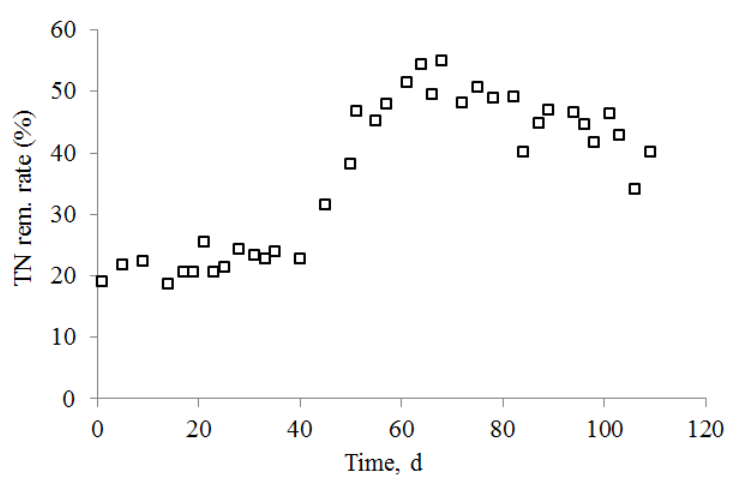

Fig. 4. Total nitrogen removal during study.

It is remarkable how other authors [19], [20] have reported that the performance of system was only irreversibly damaged with a much more intense ultrasound treatment than the one in US2. Indeed, in these studies, conditions of treatment were, respectively for [19] and [20]: fraction of sludge treated daily (SP) $30 \%$ and $28.5 \%$ with an $\mathrm{E}_{\mathrm{S}}$ of 72 $\mathrm{MJ} / \mathrm{Kg}$ and $108 \mathrm{MJ} / \mathrm{kg}$. The synergic effect of the combined process of ultrasound treatment with OSA process exposure could lead to a more efficient energy consumption and thus to an economical advantage.

\section{E. Total Nitrogen (TN) Removal}

The measured values of $\mathrm{TN}$ removal rate during the three stages of study are represented in Fig. 4.

Total nitrogen removal rate during ASP phase was $21.95 \% \pm 1.98$. When the pilot plant was operating with combining system, this rate increased to $47.28 \% \pm 6.64$ during US1 stage. OSA process has been reported to improve TN removal [1]-[21], but previous research carried out with the same pilot plant operating only OSA process [8], had lower TN removal rate $(38.02 \%)$ that in combining system of the present study. Same finding was described in Meng et al [13]. One reason for the enhancement of TN removal process is that application of ultrasonication supplies an extra carbonaceous source with high denitrification rate [21]. Increasing the intensity of ultrasonication at US2 resulted in a decrease of TN removal rate, being at any case over $30 \%$ but with marked decreasing trend. The average value for TN removal at US2 stage was $42.86 \% \pm 6.01$.

\section{CONCLUSIONS}

The combining OSA process + US process achieved a higher sludge reduction rate than OSA process only. Moreover, performance of plant is better in combining process when a moderate ultrasound treatment is applied.

\section{REFERENCES}

[1] Paul and Y. Liu, Biological Sludge Minimization and Biomaterials/Bioenergy Recovery Technologies, First Ed. Wiley, NJ, 2012.

[2] R. Ferrentino, M. Langone, F. Merzari, L. Tramonte, and G. Andreottola, "A review of anaerobic side-stream reactor for excess sludge reduction: Configurations, mechanisms, and efficiency," Crit. Rev. Env. Sci. Technol., vol. 46, no. 4, pp. 382-405, 2016.

[3] P. Romero, M. D. Coello, J. M. Quiroga, and C. A. Aragón, “Overview of sewage sludge minimization: techniques based on cell lysis-cryptic growth," Desalin. Water Treat, vol. 51, no. 31-33, pp. 5918-5933, 2013.

[4] American Public Health Association (APHA), American Water Works Association (AWWA), Water Environment Federation (WEF), Standard Methods for the Examination of Water and Wastewater, 21th Ed., APHA, Washington DC 2005.

[5] P. M. R. Romero, A. R. Jiménez, C. A. Aragón, J. M. Quiroga, and M. D. Coello, "Changes in enzymatic and microbiological activity during adaptation of a conventional activated sludge (CAS) to a CAS-oxic-settling-anaerobic (OSA) adapted process," Desalin. Water Treat, vol. 57, no. 6, pp. 2719-2725, 2016.

[6] F.-X. Ye, R.-F. Zhu, and Y. Li, "Effect of sludge retention time in sludge holding tank on excess sludge production in the oxic-settling-anoxic (OSA) activated sludge process," J. Chem. Technol. Biotechnol, vol. 83, no. 1, pp. 109-114, 2008.

[7] M. Coma, S. Rovira, J. Canals, and J. Colprim, "Minimization of sludge production by a side-stream reactor under anoxic conditions in a pilot plant," Bioresour. Technol, vol. 129, no. 0, pp. 229-235, 2013.

[8] P. Romero, "Progress in the application of techniques to sewage sludge reduction: OSA process and ozonation," Ph.D. dissertation, University of Cadiz, Spain, 2015.

[9] Z. Zhou, W. Qiao, C. Xing, C. Wang, L.-M. Jiang, Y. Gu, and L. Wang, "Characterization of dissolved organic matter in the anoxic-oxic-settling-anaerobic sludge reduction process," Chem. Eng. $J$, vol. 259, pp. 357-363, 2015.

[10] B. Xie and H. Liu, "Enhancement of biological nitrogen removal from wastewater by low-intensity ultrasound," Water Air Soil Poll, vol. 211, no. $1-4$, pp. $157-163,2010$.

[11] G. E. Zengin, "Respirometric evaluation of biodegradation kinetics for ultrasonic disintegrated domestic sludge," Desalin. Water Treat, vol. 57, no. 2, pp. 582-590, 2016.

[12] M. Zheng, Y.-C. Liu, K.-N. Xu, C.-W. Wang, H. He, W. Zhu, and Q. Dong, "Use of low frequency and density ultrasound to stimulate partial nitrification and simultaneous nitrification and denitrification," Bioresource Technology, vol. 146, pp. 537-542, 2013.

[13] Z. H. Meng, W. Q. Guo, S. S. Yang, and S. L. Yu, "Sludge reduction in anaerobic-anoxic-oxic system by lysis-cryptic growth using ultrasound pretreatment," Adv. Mat. Res, vol. 955-959, pp. 2687-2691, 2014.

[14] S. Rodriguez-Perez and F. G. Fermoso, "Influence of an oxic settling anoxic system on biomass yield, protozoa and filamentous bacteria," Bioresour. Technol, vol. 200, pp. 170-177, 2016.

[15] F. Wang, S. Lu, and M. Ji, "Components of released liquid from ultrasonic waste activated sludge disintegration," Ultrason. Sonochem, vol. 13 , no. 4, pp. 334-338, 2006 
[16] K.-J. An and G.-H. Chen, "Chemical oxygen demand and the mechanism of excess sludge reduction in an oxic-settling-anaerobic activated sludge process," J. Environ. Eng, vol. 134, no. 6, pp. 469-477, 2008.

[17] S.-S. Yang, W.-Q. Guo, Y.-D. Chen, Q.-L. Wu, H.-C. Luo, S.-M. Peng, H.-S. Zheng, X.-C. Feng, X. Zhou, and N.-Q. Ren, "Economical evaluation of sludge reduction and characterization of effluent organic matter in an alternating aeration activated sludge system combining ozone/ultrasound pretreatment," Bioresour. Technol, vol. 177, pp. 194-203, 2015.

[18] J. Marin-Hernandez, "Excess sludge reduction during activated sludge municipal wastewater treatment by integrating an anoxic holding tank and post-ultrasound treatment to enhanced biomass maintenance metabolism," Ph.D. dissertation, University of Ottawa, Canada, 2012.

[19] J. He, T. Wan, G. Zhang, and J, Yang, "Ultrasonic reduction of excess sludge from activated sludge system: Energy efficiency improvement via operation optimization," Ultrasonics Sonochemistry, vol. 18, no. 1, pp. 99-103, 2011

[20] G. Zhang, P. Zhang, J. Yang, and Y. Chen, "Ultrasonic reduction of excess sludge from the activated sludge system," Journal of Hazardous Materials, vol. 145, no. 3, pp. 515-519, 2007.

[21] P. Foladori, V. F. Velho, R. H. R. Costa, L. Bruni, A. Quaranta, and G. Andreottola, "Concerning the role of cell lysis-cryptic growth in anaerobic side-stream reactors: The single-cell analysis of viable, dead and lysed bacteria," Water Res, vol. 74, pp. 132-142, 2015.

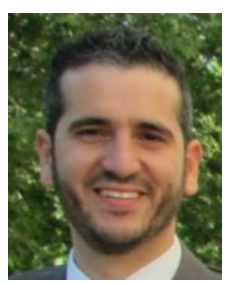

P. M. Romero-Pareja was born in Granada (Spain) in 1981. He is PhD. in Environmental Technologies Department in University of Cadiz (2015). He completed B.Sc. and M.Sc. studies in chemical engineering (University of Granada, 2006) and a M.Sc in environmental engineering (University of Granada, 2007). He is currently with a postdoctoral contract from Regional Government of Andalucía. He has collaborated with international research institutions from Italy, Nederland and Armenia.

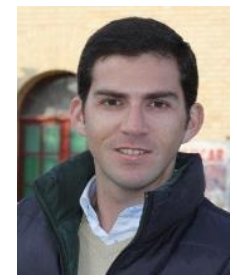

C. A. Aragon-Cruz was born in Cádiz (Spain). He obtained a Ph.D. degree in environmental technologies at the University of Cadiz. He is now a researcher and project manager at the Foundation CENTA (Seville, Spain). His research interests cover wastewater treatment in small populations (through conventional and natural tech.), sewage sludge minimization and valorization and resources recovery from sewage in the context of the Circular Economy. He also participates in international cooperation projects for sustainable sanitation and water treatment (in India, Palestine, and Latin America, among others).

J. M. Quiroga was born in Spain (1955). He obtained a Ph.D. degree in chemistry at the University of Cádiz. He is full professor in the field of environmental technology from 2004 at the Department of Environmental Technology of Faculty of Marine and Environmental Science Faculty. He has been dean of Faculty for four years (April 2012-april 2016). His research interest covers water treatment, environmental contamination, and waste management and treatment.

M. D. Coello was born in Cadiz. She obtained a Ph.D. degree in environmental technologies at the University of Cádiz. She is now full professor in the field of environmental technology at Department of Environmental Technology of Faculty of Marine and Environmental Science Faculty where is involved in European project management. 